\title{
THE THEATRE ILLUSTRATED
}

\section{Scene Design in the American Theatre}

From 1915 to 1960

\section{by Orville K. Larson}

A new stagecraft movement began in Europe just prior to World War I, reaching the United States with the apppearance of Robert Edmond Jones. Almost single-handedly, Jones turned stage decoration into a new art which became more than mere scene painting. Richly illustrated, Scene Design in the American Theatre chronicles this important transformation between 1915 and 1960. The American scene designers who emerged from the new stagecraft movement were of a different breed from their

European counterparts and were among the most articulate artists in the American theatre. Orville $K$. Larson has spent sixty years as a devoted student and critic of American scene design, witnessing first-hand many of the productions discussed in this ground-breaking study. This book is an invaluable guide to theatre designers and indeed anyone interested in the theatre and its history. 568 pages, illustrated, $£ 38.00$ cloth, $€ 23.75$ paper

\section{The Theatre in History by George R. Kernodle}

The development of theatre, according to Kernodle, is an outgrowth of human impulses - from the most primitive to the most refined - which help us to understand ourselves in the context of our own time and culture. The Theatre in History is a sensitive and appreciative study of that development.

The author examines the theatre from primitive Egyptian and ancient oriental to Romantic drama of the nineteenth century, even providing a glimpse of the twentieth century through the theatrical art of Charlie Chaplin. It discusses theatre's primitive origins, its artistic shaping through the ages, its stagecraft, and its various cultural interrelationships. Kernodle devoted his life to the theatre - directing, acting, and witnessing hundreds of performances. In so doing he gained a rare understanding of the theatre. For the student of the theatre, this extensively illustrated book will serve as an excellent source of valuable facts and analyses. 600 pages, illustrated, $£ 28.50$ cloth, $£ 17.10$ paper

\section{The University of Arkansas Press 1 Gower Street London WC1E 6HA}




\title{
THE INTERNATIONAL FEDERATION FOR THEATRE RESEARCH \\ LA FEDERATION INTERNATIONALE POUR LA RECHERCHE THEATRALE
}

\author{
Founded in 1957 with the following aims: \\ To promote in all countries international liaison between \\ organizations and individuals devoted to theatre research. \\ To organize international conferences and symposia. \\ To obtain facilities in libraries, museums, etc., for \\ theatrical research workers of all countries. \\ To submit to the authorities of all countries the desirability \\ of creating courses, institutes and chairs of theatre research.
}

The I.F.T.R. has the following sections:

THE VENICE INTERNATIONAL INSTITUTE FOR THEATRE RESEARCH

THE UNIVERSITIES COMMISSION, specially charged with research within universities and the promotion of teaching of Theatre Studies throughout the world.

All members receive the journal Theatre Research International published by the Oxford University Press in association with the I.F.T.R. and a news Bulletin twice a year.

INSTITUTIONAL

MEMBERS:

INDIVIDUAL

MEMBERS:

\section{MEMBERSHIP AND ANNUAL SUBSCRIPTIONS}

Bodies whose sole function is theatre research. $200 \mathrm{Sw} . \mathrm{F}$.

Individuals who wish to participate in the work of the I.F.T.R. and to support it. $70 \mathrm{Sw}$. F. reduced to $65 \mathrm{Sw}$. F. for individuals already belonging to a national institutional member.

Enquiries and application for membership should be addressed to

Membership Secretariat, IFTR/FIRT

14 Woronzow Road, London NW8 6QE, Great Britain

\section{THEATRE RESEARCH / RECHERCHES THEATRALES}

The International Federation published the journal Theatre Research/Recherches Théâtrales from 1959 to 1975 when it was succeeded by Theatre Research International. During these years many important articles of original research were published covering the whole field of theatre history from the earliest times, and particularly Shakespeare and the Elizabethan period, to more recent figures such as Strindberg, Craig and Beckett. There have been special issues on the themes of Opera, the Playwright as Director, and Reinhardt; a check-list of world theatre on records; and reports on International Conferences and Symposia of the I.F.T.R.

In all 14 volumes were published in 36 issues including a complete index. Most back issues are still available.

University and institutional libraries, and especially those who have subscribed to the new journal Theatre Research International, are recommended to take this opportunity of completing their holding of the earlier issues of this publication, while copies last.

Price: per issue 4 (\$6); per volume $\mathrm{f} 8(\$ 12)$ plus postage

A few complete runs of the 14 volumes (with two issues in facsimile) are available at $\mathbf{1 7 0}(\$ 100)$. Postage extra.

Enquiries and Orders are invited to

THEATRE RESEARCH

14 WORONZOW ROAD, LONDON NW8 6QE 